\title{
The 1982 United Nations Convention on the Law of the Sea as an Agreement Solving Some Issues with Aspects of Strategic Importance
}

\author{
By Yulia A. Shabalina*
}

\begin{abstract}
The purpose of this article is to focus mainly on two aspects, which the author considers to be aspects of strategic importance. The first is to study the legal regulation of marine scientific research in the exclusive economic zone and on the continental shelf. The second is to examine the regime of the exploitation of the continental shelf beyond 200 nautical miles from the baselines from which the breath of the territorial sea is measured. The author also finds it interesting to distinguish the rights of coastal and non-coastal states in the above mentioned issues according to the UNCLOS from the national law taking as an example the law of the Russian Federation.
\end{abstract}

Keywords: Exclusive economic zone; Continental shelf; Coastal and non-coastal states; Natural resources; Maritime scientific research; Geological examination; Exploration and exploitation of mineral resources; Protection of the marine environment; UNCLOS;

\section{Introduction}

Russia borders on 13 seas which belong to the basins of 3 oceans. The Atlantic Ocean includes the Baltic, the Black Seas and the Sea of Asov. The Arctic Ocean embraces the Barents, the Pechora, the White, the Kara, the Laptev, the East Siberian and the Chukchi Seas. The Pacific Ocean encompasses the Bering Sea and the Seas of Okhotsk and Japan. The thirteenth sea is the Caspian Sea - the closed lake. The length of the border of the Russian Federation amounts to $60933 \mathrm{~km}, 38808 \mathrm{~km}$ of which is a maritime boundary.

The length of a state's sea coast does not equate to its political and economic activity in the World Ocean, however. In previous times access to the sea could provide a coastal state with manifold opportunities to obtain the status of a "maritime power". Although we do not use such notions now and consider each other as economic partners, until today access to the sea is an enabler of the enhanced commerce of a coastal state ${ }^{1}$.

In order for the interests of coastal and non-coastal states not to collide, it is of a paramount importance for a country to abide by the international maritime law. The 1982 United Nations Convention on the Law of the $\mathrm{Sea}^{2}$ is the main convention focused on the protection of the marine environment, the security

\footnotetext{
*Master of the International Private and Civil Law; Ph.D. candidate in Moscow State Institute of International Relations (University) of the Ministry of Foreign Affairs of the Russian Federation. Moscow, Russia. E-mail: julia.shabalina90@gmail.com

${ }^{1}$ Analogously, when we deal with the international law, we shall substitute the geopolitical notion "political ambitions" with more neutral and juridically appropriate "state interests".

${ }^{2}$ Hereinafter "the UNCLOS".
} 
of the interests of the national fishing and transport organisations, the conservation and management of living and non-living natural resources and other issues of the maritime law.

As stated by the UN General Assembly in its annual resolutions on the oceans and the law of the sea, "it is necessary to bring the national law to the conformity with the provisions of the UNCLOS"3. The Russian Federation signed the UNCLOS on $10^{\text {th }}$ of December, 1982. Russia ratified the Convention on $12^{\text {th }}$ of March, 1997. Since then the UNCLOS has become the integral part of Russian law according to Par. 4 of Art. 15 of the 1993 Constitution of the Russian Federation ${ }^{4}$.

Explaining why the Convention should be ratified by the USA, Prof. J. Daff, the American specialist in the international law, singled out all the directions touched upon in the UNCLOS where many questions of dispute for the USA had already been solved. They are "the national security, the military perspectives, the diplomacy, the commercial shipping, the scientific issues, the delimitation of the continental shelf, the industrial prospects and the protection of the environment". Russian scientists Kolodkin, Guzuljak and Bobrova maintain that "these priority directions fully coincide with the interests of the Russian Federation" ". Thus, the UNCLOS is considered to be one of the best solutions to the issues of strategic importance for the security of the interests of any independent state.

\section{Outline and Literature Review of the Topic}

This article is constructed so that we will deal first with the question of marine scientific research and then we will proceed with the exploration and the exploitation of mineral resources. The author has chosen this approach because she thinks that undertaking researches of mineral resources could be the prerequisite of the exploration and the exploitation of such, if a country decides to continue to explore and to exploit the resources at the site. It is supposed that this statement is true when the activities are undertaken by one or by many actors.

If we consider the research and the explorations to be conducted by one coastal state, the article will lose the strategic aspect of its content. The theme becomes disputable when there is more than one state in the mentioned activities. That is why we are going to investigate how the international maritime law regulates the activities of two or more coastal states as well as the activities of coastal, non-coastal states and professional international organisations inter se. There is also an assumption that marine researches are sometimes launched due

\footnotetext{
${ }^{3}$ Kolodkin, Guzuljak and Bobrova (2007) at 28.

${ }^{4}$ Par. 4 of Art. 15 of the Constitution of the Russian Federation (1993) states that "the universallyrecognised norms of the international law and international treaties and agreements of the Russian Federation shall be a component part of its legal system. If an international treaty or an agreement of the Russian Federation establishes other rules than those envisaged by law, the rules of the international agreement shall be applied".

${ }^{5}$ Kolodkin, Guzuljak and Bobrova (2007) at 28.
} 
to a wish of the community to receive more information of a different kind from the waters of a coastal state. This idea is not going to be considered in the article because of the absence of competing interests.

The analysis is built so that only far remote marine areas are taken into account. We will study the exclusive economic zone and the continental shelf as the objects of research. The continental shelf beyond 200 nautical miles from the baselines from which the breath of the territorial sea is measured ${ }^{6}$ seems to the author to be the most interesting issue to research, because this area of the exploitation of the mineral resources is under no state`s jurisdiction, which generates a rivalry among the most strategically powerful states in the epoch of the lack of the natural resources as such.

There is no legal document or a piece of literature where one can find a better explanation of the regimes of water spaces rather than they are indicated in the UNCLOS. Some details on the continental shelf could be found in Annex II: Commission on the limits of the continental shelf. This is a part of the UNCLOS. Another significant source of information here is the Rules of the Procedure of the Commission on the Limits of the Continental Shelf, adopted in the twenty first session of the Commission on the limits of the Continental Shelf on $17^{\text {th }}$ of March $-18^{\text {th }}$ of April, 2008. Both documents of the Commission are placed on the page of the Website of the UN Commission ${ }^{7}$.

Being a coastal state, Russia has some federal laws on both merits: on the conducting of marine researches and on the exploitation of resources in different parts of the sea. I have analysed the Federal Law "About the Continental Shelf of the Russian Federation", the Rules to conduct a marine scientific research in the internal waters, the territorial sea, the exclusive economic zone and on the continental shelf of the Russian Federation" and the Decree "About the continental shelf of the Russian Federation in the Okhotsk Sea" "I I have also made general references to the 1993 Constitution of the Russian Federation and to the scientific book, dedicated to the issues of the international maritime law ${ }^{11}$.

\section{The Conducting of a Marine Scientific Research in the Exclusive Economic Zone and on the Continental Shelf under the 1982 UN Convention on the Law of the Sea and the Russian Legislation}

The conducting of a marine scientific research in the exclusive economic zone and on the continental shelf is regulated by one article of the UNCLOS. Art. 246 of the Convention empowers a costal state to regulate, to authorise and to conduct a marine scientific research in its exclusive economic zone and on its continental shelf. Paragraph 5 of this Article provides for the grounds when the

\footnotetext{
${ }^{6}$ Hereinafter "the continental shelf beyond 200 nautical miles".

${ }^{7}$ http://www.un.org/depts/los/clcs_new/commission_documents

${ }^{8}$ No $187-F Z$ of November 30, 1995

${ }^{9}$ No 391 of July 30, 2004

${ }^{10}$ No 845 of August 15, 2015

${ }^{11}$ Kolodkin, Guzuljak and Bobrova (2007).
} 
costal state in its discretion withholds its consent to the conducting of the marine scientific research project of another state or a competent international organisation in the exclusive economic zone or on the continental shelf of the coastal state, if, according to Subparagraph "a", the project is of a direct significance for the exploration and exploitation of natural resources, whether living or non-living.

Judging by Subparagraphs "b" and "c", we find that they address only two subjects that are allowed to make a research: a state and a competent international organization. At the present time there is a set of organisations and systems that enable people to select data and to keep records in the marine environment. Among such systems are the Organisation of a regular process of the marine environment estimation, the Global system of the Earth monitoring systems, the Argo Program and the Ocean data, instruments and devices acquisition system. If the activities of such organisations and systems fall under the activity regulated by Par. 5 of Art. 246, such organisations and systems should request the coastal state`s permission to conduct a research.

Since the international law refers to national legal procedures anyway, the national legislation of a costal state must contain, and they usually do, more elaborated provisions for performing a research process, especially for the admission of the research applicants. The Rules to conduct a marine scientific research in the internal waters, the territorial sea, the exclusive economic zone and on the continental shelf of the Russian Federation ${ }^{12}$ regulate the process of making a research, including how to assess a research and to make a decision upon the received data.

The Rules also provide for the grounds to withhold the applicants consent of a marine scientific research project. They are listed in Art. 38 of Chapter V "The grounds for issuing a licence". It regulates analogous legal relations in a more detailed way then the UNCLOS does. A scientific research must not only be "of a direct significance for the exploration and the exploitation of natural resources", as stated in the Convention, but also be "related to the examination, the search, the exploration and the exploitation of non-living natural resources or be related to the examination, the exploration and the exploitation of living resources"13. Consequently, the scope of the legal relations to be regulated by the Russian legislation is wider than the one considered by the international law.

At the same time, one could argue that enumerating different activities "of a direct significance for the exploration and the exploitation of natural resources" hardly makes any legislation more elaborated. Indeed, the national law is a vivid reflection of the international law. - Regardless, one may suppose that, when alleging in the court, it is easier for a legal entity or a physical person to refer to a concrete provision in the national law than to prove that its actions fall under the ambiguous wording of the issue in the international law.

\footnotetext{
${ }^{12}$ No 391 of 30 July, 2004

${ }^{13}$ Subparagraph "a" of Art. 38 of the Rules to conduct a marine scientific research in the internal waters, the territorial sea, the exclusive economic zone and on the continental shelf of the Russian Federation
} 
The Federal Law "About the Continental Shelf of the Russian Federation"14 is another example of Russian law where the national legislator establishes more detailed provisions than the UNCLOS does. For example, it prescribes the time limits to apply for a license. According to Art. 26 of the Federal Law, the competent international organisation, where the Russian Federation is a party or with which the Russian Federation has signed a bilateral treaty, can start a research, if the Russian Federation has approved of the project and its federal bodies have not sent any objection four months after the application was sent. In case the applicant is a foreign state or a Russian entity, according to Art. 24 of the Federal Law, it is empowered to make a research in terms, provided for in the application, but at least six months after the request or the required additional information was sent. The author believes that the national law will always have more elaborated provisions in comparison with the Convention, because it is the authorities of the coastal state who face the procedure of the direct request.

Another ground to withhold the consent for the research, established in Par. 5(b) of Art. 246, is when the project involves the drilling into the continental shelf and the use of the explosives or the introduction of harmful substances into the marine environment. The Convention vests a coastal state with the exclusive right to regulate the drilling and the use of explosives on its continental shelf. In Russia the federal executive bodies authorizing other entities to conduct researches and to issue licenses do it in coordination with the Federal Service for the technical and export control of the Russian Federation that gives its recommendation having checked the activities of a foreign entity in accordance with the Ruling of the RF Government "About the placement and the use on the territory of the Russian Federation of the foreign technical means of control and observation on the exclusive economic zone of the Russian Federation". ${ }^{15}$

Prohibited activities include drilling, the use of explosives, the burial of waste of different types of production, carbon dioxide burial, oil spills, which pollute the marine environment. In order to control such activities for the purpose of the prevention and reduction of the pollution the coastal state exercises its jurisdiction following the principle of the conducting of marine scientific research for peaceful purposes, as provided for in Art. 240(a) of the Convention.

Art. 25 of the Federal Law "About the Continental Shelf of the Russian Federation" lists the grounds to refuse native or foreign applicants to research. The grounds can be classified by different criteria.

By the danger posed to the world the research is not allowed if it threatens the national defence and foments war.

By the danger to the protection of the environment the research must not be undertaken if it is incompatible with the rules of environment protection, if it is of a direct significance to the regional geological examination, the exploration and the exploitation of the mineral resources of the continental shelf. The

\footnotetext{
${ }^{14}$ No 187 of 30 November, 1995

${ }^{15}$ No 633 of 29 August, 2001.
} 
research must not be authorised if it includes the creation, the exploitation and the use of artificial islands, installations, facilities, drillings, explosives and pneumatic units on the continental shelf.

The third basis for withholding the coastal state's consent is the threat to the sovereign rights and the jurisdiction of the coastal state for the purpose of the exploring and the exploiting, the conserving and the managing of the natural resources on the continental shelf. If some areas are already declared by the Government to be explored by the national resources, no other entity can replace them. Likewise, the consent to the research must be withheld when a native or a foreign applicant is bound to fulfil obligations to the Russian Federation arising out previous marine scientific researches. Finally, the fourth ground to refuse to research can be qualified as being contradictory to the factual information: for example, when the applicant provides unreliable or inadequate information about its activities.

What research on the continental shelf beyond 200 nautical miles is concerned, Russian bodies cannot withhold the consent to research on the abovementioned grounds except for the regions where the Government announced an intent to explore the continental shelf and investigate its mineral resources and water bio resources. The information of such regions shall be placed in the "Notice to mariners".

\section{The Regime of the Exploitation of the Natural Resources of the Continental Shelf Beyond 200 Nautical Miles from the Baselines from which the Breath of the Territorial Sea is Measured under the $1982 \mathrm{UN}$ Convention on the Law of the Sea; The Example of the Russian Federation on the Extension of its Continental Shelf}

At the present time a coastal state can enjoy various regimes of the exploitation of natural resources in its water partitions. The Convention distinguishes them according to the status of the water area: the territorial sea, the exclusive economic zone, the continental shelf, the continental shelf beyond 200 nautical miles from the baselines from which the breath of the territorial sea is measured.

Before focusing on the last, we suggest we briefly describe all of the aforementioned and distinguish the difference in the regimes of the exploration and the exploitation of mineral resources. The regime of the territorial sea implies that the coastal state extends its sovereignty on the adjacent belt of the sea as well as to its bed and subsoil under Art. 2 of the UNCLOS. Consequently, only the coastal state is empowered to explore and to exploit its mineral resources.

The regime of the exclusive economic zone means that the coastal state has sovereign rights for the purpose of the exploring and the exploiting, the conserving and the managing of the natural resources, whether living or nonliving, of the waters superjacent the seabed and of the seabed and its subsoil according to Art. 56 of the UNCLOS. In exercising of its rights and performing of its duties the coastal state shall have due regard for the rights and duties of 
other states and shall act in the manner compatible with the provisions of the Convention. The rights and the duties of other states in the exclusive economic zone are listed in Art. 58 of the Convention. Unfortunately, none of them is connected to the exploitation of the mineral resources. Although two of them could be vicariously linked to the business - the laying and the operation of submarine cables and pipelines.

The third status of the sea is the continental shelf. The regime of the continental shelf provides the coastal state with the exercising of its sovereign rights for the purpose of the exploring and exploiting of its natural resources. Art. 77 of the Convention states that these rights "are exclusive in the sense that if the coastal state does not explore the continental shelf or exploit its natural resources, no one may undertake these activities without the express consent of the coastal state"16. It is important to note that the sovereign rights of the coastal state do not depend on the effective or notional occupation of the area by the coastal state. Neither do they depend on any express proclamation of the coastal state.

The regime of the exploitation of the continental shelf beyond 200 nautical miles is finally the one we would like to specify on. The Convention allows the coastal state to explore and to exploit the mineral resources on this "territory" provided it makes payments or contributions to other states according to Art. 82 of the UNCLOS. Part 2 of this Article provides for the calculative details of the contribution. The contribution shall be made annually with respect to all of the production at a site after the first five years of the production. For the sixth year, the rate of payment shall be 1 per cent of the value or volume of the production at the site. The rate shall increase by 1 per cent for each subsequent year until the twelfth year and shall remain at 7 per cent thereafter. There is only one exemption from this rule, set down in Par. 3 of Art. 82 of the UNCLOS: a developing state which is the importer of the mineral resource produced on its continental shelf shall be exempt from making payments or contributions in respect of that mineral resource.

One might ask whether it is possible for a non-coastal state, a legal entity or a specified international organisation to explore the continental shelf beyond 200 nautical miles and exploit its mineral resources. Since the UNCLOS and the documents of the Commission on the Limits of the Continental Shelf do not name entities other than coastal states, we come to the conclusion that only the coastal states - Parties to the Convention - can explore the continental shelf beyond 200 nautical miles and exploit its mineral resources. Likewise, the Rules of Procedure of the Commission on the Limits of the Continental Shelf ${ }^{17}$ refer to the coastal states as the sole possible addressees.

Interesting enough is that the international law permits a coastal state to establish the outer limits of its continental shelf beyond 200 nautical miles and exercise sovereign rights over the natural resources there. The UNCLOS prescribes the extension of the continental shelf as well. In accordance to Art. 4 of "Annex II. The Commission on the limits of the continental shelf" to the

\footnotetext{
${ }^{16}$ Paragraph 2 of Art. 77 of the UNCLOS

${ }^{17} \mathrm{CLCS} / 40 /$ Rev. 1
} 
Convention, a coastal state shall submit particulars of the limits to the Commission alongside with the supporting scientific and technical data within 10 years of the entry of the Convention into force for that state.

The coastal state is also obliged to follow the Rules of the Procedure of the Commission on the Limits of the Continental Shelf ${ }^{18}$ adopted in the twenty first session of the Commission on the limits of the Continental Shelf on $17^{\text {th }}$ March $-18^{\text {th }}$ April, 2008. The Rules set up the - procedure for extending the outer limits of the continental shelf ${ }^{19}$. Firstly, the coastal state shall express the intent to set new limits ${ }^{20}$. The Commission shall verify whether the mainland shore limit extends to more than to 200 nautical miles, make a preliminary examination of the submission and clarifications ${ }^{21}$.

After the notification of the receipt of a submission and the publication of the proposed outer limits of the continental shelf related to the submission ${ }^{22}$ the Commission makes a recommendation, which the coastal state can either accept or decline $^{23}$. In case of acceptance, the state fixes the final limits. If the state does not agree with the Commission`s recommendations, the state shall draw a new statement ${ }^{24}$. The final step of this procedure takes place when the coastal state delivers the map of the limits to the International Seabed Authority ${ }^{25}$.

Having kept the term of 10 years after the Convention came into force for the Russian Federation, the RF Government made a joint submission to the Commission on the limits of the continental shelf to extend the limits of the continental shelf of the Sea of Okhotsk and of the Arctic Ocean beyond 200 nautical miles in 2001. For the purposes of convenience, it was decided to divide the submission into two.

On 11th March, 2014 the Commission gave positive recommendations to the Russian authorities to set the outer limits of the continental shelf beyond 200 nautical miles in the Sea of Okhotsk. The Decree "About the continental shelf of the Russian Federation in the Okhotsk Sea" ${ }^{\text {26 }}$ declared that the sea bed and the subsoil (enclave) beyond 200 nautical miles situated in the central part of the Okhotsk sea and limited such that its borders are the borders of the exclusive economic zone of the Russian Federation in the Okhotsk sea shall be affirmed to be the continental shelf of the Russian Federation. It is also stated in the Decree that the boundaries of the continental shelf in the Okhotsk Sea are final and mandatory for other states according to Par. 8 of Art. 76 of the UNCLOS.

\footnotetext{
${ }^{18}$ Hereinafter "Rule" or "Rules".

${ }^{19}$ The full procedure of submission is described in Part XI "Submission by a coastal State" (Rules $45-54$ ) of the Rules of the Procedure of the Commission on the Limits of the Continental Shelf.

${ }^{20}$ Rule 45.

${ }^{21}$ Rule 49.

${ }^{22}$ Rule 50.

${ }^{23}$ Rule 53.

${ }^{24}$ Par. 4 of Rule 53.

${ }^{25}$ Rule 54

${ }^{26}$ No 845 of 15 August, 2015
} 


\section{Conclusion}

The conducting of marine researches is not often discussed in the scientific literature, since the theme is of a technically descriptive nature and contains little argumentative information. The conducting of a marine research is slightly indicated in the legal documents too, because there are exceptionally few issues of strategic importance here, except when tackling the exclusive economic zone and the continental shelf. Contrarily, mineral resources exploitation is by far the most often discussed topic in the international maritime law. One has already distinguished the third area of investigation: the territory of the continental shelf beyond 200 nautical miles that has been considered from the two perspectives of the article. The author hopes that such construction of the paper makes it unique in the accumulation of the information on the issues of the strategic importance in the specified areas of the international maritime law.

The regulation of the performance of marine scientific researches in general is fully provided for by the "Constitution for the Oceans" legislation. Art. 246 of the Convention sets forth the right of non-coastal states and organisations to request to research in the exclusive economic zone and on the continental shelf of the coastal state. Par. 5 of this Article contains the legal grounds to withhold the coastal state's consent, that, being elaborated by the Russian law or any other coastal state`s legislation, can be classified as being harmful to the community`s wellbeing, to the protection of the environment, to the coastal state`s sovereignty and containing factual mistakes.

In comparison to the international law, the national legislation is more detailed in terms of the request for the research, expanding the scope of activities, mentioned in Art. 246 of the UNCLOS. In Russia the main acts regulating this activity are the Rules to conduct a marine scientific research in the internal waters, the territorial sea, the exclusive economic zone and on the continental shelf of the Russian Federation, confirmed by the Ruling of the Government of the Russian Federation No 391 of 30 July, 2004 and the Federal Law "About the Continental Shelf of the Russian Federation" No 187 of 30 November, 1995. The Rules list actions that are "of a direct significance for the exploration and the exploitation of natural resources" 28 - the threat that the coastal state shall not allow when giving a license for marine scientific researches. The Federal law "About the Continental Shelf of the Russian Federation" lists the requirements for a state to receive a license to research on the continental shelf and names the cases when it can be rejected. Thus, the Convention sets up short and basic norms for coastal and non-coastal states in the marine scientific research activity. It provides the "gold standard" for the domestic law of a coastal state, according to which its federal services will permit or reject performing researches in the water areas under the sovereignty of their state. The wording "activities of a direct significance for the exploration and the exploitation", which has been considered in the article, is one of the examples of such norms.

\footnotetext{
${ }^{27}$ Koh (1982).

${ }^{28}$ Par. 5(a) of Art. 246 of the UNCLOS.
} 
A general conclusion on scientific research may sound like this: any state or an international organisation can conduct researches in all kinds of water spaces under the jurisdiction of the coastal state with the permission of the latter. Such permission is not needed for the researches on the continental shelf beyond 200 nautical miles, where coastal states don't exercise their jurisdiction according to Par. 6 of Art. 246 of the UNCLOS. There is only one exception from this rule: when a coastal state has publicly designated some areas on the continental shelf beyond 200 nautical miles under the exploitation or detailed exploratory operations and reported about it to the community within a reasonable period of time.

The opposite conclusion shall be made when considering the continental shelf beyond 200 nautical miles from the angle of its exploration: only the coastal state can explore this "territory" and exploit its natural resources. When doing so, it must make payments to the specially appointed body according to Art. 82 of the UNCLOS. This body will distribute the payments among other states on the principle of justice and with the due regard of the interests and needs of the developing states, particularly the least developed and the landlocked. A developing coastal state that is the importer of the resources excavated from its continental shelf is exempt from this duty. A coastal state can enjoy its jurisdiction over the territory beyond 200 nautical miles if it succeeds in extending its continental shelf with the Commission on the limits of the continental shelf.

We have also ascertained that the UNCLOS does not contain the provisions for the exploitation of the natural resources on the continental shelf beyond 200 nautical miles by the non-coastal states, professional legal entities or specified international organisations. That is why we have determined that, firstly, only a coastal state and, secondly, only a Party to the Convention, are allowed to exploit the mineral resources on the discussed marine area.

\section{References}

Duff, J.A. (2004) 'Note on the United States and the Law of the Sea: Looking Back and Moving Forward' in Ocean Development \& International Law 35(3):195-219

Kolodkin, A.L., Guzuljak, V.N. and I.V. Bobrova (2007). The World Ocean: International Legal Regime, Main Problems. Moscow: Statut. [In Russian].

Koh, T.T.B. (1982). Remarks by Tommy T.B.Koh, of Singapore, President of the third United Nations Conference of the Law of the Sea adapted from statements by the president of 6 and 11 December 1982 at the final session of the Conference at Montego Bay. Available at: https://www.un.org/depts/los/convention_agreements/ texts/koh_english.pdf

\section{Legislation}

The Constitution of the Russian Federation of 12 December, 1993.

The Decree "About the continental shelf of the Russian Federation in the Okhotsk Sea" No 845 of 15 August, 2015. 
The Federal Law "About the Continental Shelf of the Russian Federation" No 187-FZ of 30 November, 1995.

The Rules to conduct a marine scientific research in the internal waters, the territorial sea, the exclusive economic zone and on the continental shelf of the Russian Federation, confirmed by the Ruling of the Government of the Russian Federation No 391 of 30 July, 2004.

The Rules of the Procedure of the Commission on the Limits of the Continental Shelf, adopted on the twenty first session of the Commission on the limits of the Continental Shelf on March 17-April 18, 2008, CLCS/40/Rev.1.

\section{International Convention}

The 1982 United Nations Convention on the law of the sea. 
